\title{
PENGARUH GENDER INEQUALITY DALAM KELUARGA TERHADAP PERILAKU RESPONSIF GENDER PADA REMAJA
}

\author{
Audiah Anggraini ${ }^{\left.1,{ }^{*} a\right)}$, Tarma ${ }^{1, b)}$, Mulyati ${ }^{1, c}$ ) \\ ${ }^{1}$ Program Studi Pendidikan Vokasional Kesejahteraan Keluarga \\ Fakultas Teknik, Universitas Negeri Jakarta \\ Jln. Rawamangun Muka, Jakarta Timur. 13220 \\ E-mail: "a)audiahanggraini@gmail.com, b) tarmasae@gmail.com \\ c) imoel.mulyati@gmail.com
}

\begin{abstract}
Abstrak
Penelitian ini bertujuan untuk mencari pengaruh gender inequality dalam keluarga terhadap perilaku responsif gender pada remaja di SMP NEGERI 149 Jakarta. Penelitian ini dilaksanakan di SMP NEGERI 149 Jakarta. Metode penelitian yang digunakan adalah survey. Populasi pada penelitian ini adalah siswa di SMP NEGERI 149 Jakarta pada kelas VIII yang berjumlah 170 siswa dengan jumlah 120 siswa yang dijadikan sebagai responden. Uji hipotesis data yang digunakan dalam penelitian ini adalah Korelasi Koefisien Product Moment yang menyatakan korelasinya sebesar $r=-0,273$ yang artinya terdapat korelasi ke arah negatif dengan tingkat hubungan dalam kategori rendah. Hasil uji signifikansi pada koefisiennya sebesar $t=0,913$ karena nilai sig. lebih besar dari 0,05 maka diketahui bahwa korelasi antara variabel signifikan. Koefisien determinasi diperoleh sebesar $7,4 \%$. Hasil penelitian dan uji hipotesis terdapat pengaruh negatif gender inequality terhadap perilaku responsif gender pada remaja di SMP Negeri 149 Jakarta.
\end{abstract}

Kata Kunci :Gender Inequality, Keluarga, Perilaku Responsif, Remaja

\section{The Influence Of Family Gender Inequality to Gender Responsive behavior at 149 Junior High School Jakarta}

\begin{abstract}
This research aims to find the influence of family gender inequality on gender-responsive behavior at 149 Junior High School Jakarta. This research was conducted at 149Junior High School Jakarta. The methodology used a survey. The population in research is a student in grade eight of 149 Junior High School Jakarta. The hypothesis data used research is a Correlation Product Moment, that correlation of $r=-0,273$ which means correlation the relation between variables is low in the negative direction. The result from the coefficient significance is $t=0,913$ and can be concluded that the correlation coefficient is significant. The coefficient determination obtained $7,4 \%$. The hypothesis research and test are significant between family gender inequality to gender-responsive behavior at 149 Junior High School Jakarta.
\end{abstract}

Keywords : Family Gender Inequality, Gender Responsive Behavior on Teenager 


\section{PENDAHULUAN}

Perilaku responsif gender merupakan upaya kegiatan yang memperhatikan perbedaan kebutuhan antara laki-laki dan perempuan. Perilaku responsif gender adalah tindakan individu atau kelompok yang didasari oleh sikap, nilai dan pengetahuan yang dimiliki individu tersebut. Perilaku responsif gender merupakan kebiasaan baik yang semestinya terjadi pada lingkungan sosial. Menurut Tong dalam Erlangga (2014) gender merupakan konsep yang merujuk pada karakteristik yang membedakan antara laki-laki dan perempuan yang dibangun atas asumsi yang berkembang di masyarakat. Lingkungan sosial yang memperhatikan kebutuhan antara laki-laki dan perempuan menciptakan keadilan antara lakilaki dan perempuan dengan tidak merugikan gender terntentu. Pemisahan gender yang terbentuk dari struktur sosial individu mengakibatkan laki-laki maupun perempuan kesulitan dalam mengembangkan diri. Pendapat ini didukung oleh Hubeis dalam Erlangga (2014) mengatakan gender adalah suatu konsep yang menunjuk pada suatu sistem peranan dan hubungan antara perempuan dan laki-laki yang tidak ditentukan oleh perbedaan biologis akan tetapi oleh lingkungan sosial, politik dan ekonomi. Pemisahan gender menyebabkan remaja kesulitan memproporsikan diri dalam bersikap, berperilaku dan kesulitan bersaing secara sehat antar remaja untuk mencapai kesuksesan sesuai bidang dan bakatnya masingmasing. Masalah perilaku responsif gender menjadi fenomena sosial yang patut diselesaikan. Fenomena ini menjadi hal yang menarik untuk dibahas karena masih ada pemisahan gender antara laki-laki dan perempuan. Perilaku yang tidak responsif gender terjadi akibat adanya ketidakadilan gender.

Perilaku responsif gender terbentuk dari pengalaman pribadi seseorang atau kelompok, kebudayaan dan proses sosial yang memperhatikan perbedaan kebutuhan dan peran antara laki-laki dan perempuan. Menurut pendapat Mastuti (2010) responsif gender sebagai perhatian yang konsisten dan sistematis terhadap perbedaan-perbedaan perempuan dan laki-laki di dalam masyarakat yang disertai upaya menghapus hambatan-hambatan struktural dan kultural untuk mencapai kesetaraan gender. Terdapat faktor-faktor yang mempengaruhi perilaku responsif gender dikemukakan oleh Balik (2018) yang menyatakan ada dua faktor yang mempengaruhi terbentuknya sikap responsif yaitu faktor internal yang berasal dari dalam seseorang itu sendiri biasanya merupakan faktor bawaan sejak lahir dan merupakan pengaruh keturunan dari salah satu atau kedua sifat yang dimiliki orangtua, faktor eksternal biasanya dipengaruhi dari lingkungan anak dimana anak mulai belajar untuk menyesuaikan diri dengan dunia lingkungan sosialnya. Faktor lain penyebab perilaku yang tidak responsif menurut Bem dalam Erlangga (2014) kepribadian seseorang yang dipengaruhi oleh peran gender yang dimilikinya yaitu tipe maskulin terbentuk oleh budaya yang dipercaya sebagai ciri-ciri ideal bagi laki-laki, tipe feminin terbentuk oleh budaya yang dipercaya sebagai ciri-ciri ideal bagi perempuan, androgini terbentuk oleh budaya yang dipercaya bahwa sifat maskulin dan feminin menunjukan sikap ekspresif dan instrumental, dan tipe tak tergolongkan (undiferentianed). Individu androgini adalah seorang laki-laki yang asertif (sifat maskulin) dan mengasihi (sifat feminin) atau seorang perempuan yang dominan (sifat maskulin) dan sensitif terhadap perasaan orang lain (sifat feminin).

Gender inequality adalah seperangkat pemahaman yang dibangun dalam persepsi masyarakat secara turun temurun tentang ketidakadilan peran dan wewenang antara lakilaki dan perempuan. Ketidakadilan gender merupakan kondisi yang dibentuk dari lingkungan sosial dimana individu tersebut tinggal. Pendapat tersebut di dukung oleh Annisarti (2018) Gender merupakan suatu hal yang bisa dikonstruksi tergantung dimana seseorang berada dan bagaimana lingkungan mempengaruhinya, pendapat tersebut memunculkan perbedaanperbedaan pemikiran mengenai pandangan terhadap laki-laki dan perempuan di dalam 
masyarakat. Pendapat ini menekankan pada faktor lingkungan dalam menumbuh kembangkan pemahaman tentang perbedaan peran antara laki- laki dan perempuan.

Beberapa ahli menjelaskan tentang faktor-faktor penyebab gender inequality pada remaja. Masa remaja merupakan masa pencarian identitas dan pada masa remaja harus dapat melewati krisis identitas agar tidak terjadi kebingungan identitas. Salah satu penyebab kebingungan identitas remaja adalah labeling. Menurut Erianjoni (2015) seseorang yang diberi label biasanya mengikuti label yang telah ditetapkan kepada dirinya dan akan menjadi dasar orang tersebut beradaptasi sepanjang hidupnya. Labeling adalah pemberian identitas kepada seseorang yang menjadi bagian dari konsep diri seseorang. Pemberian label atau identitas biasanya didapat dari hasil interaksi sosialnya. Teori labeling disebut juga teori pelabelan atas perilaku menyimpang yang sering digunakan masyarakat terhadap penyimpangan. Menurut pendapat Turner (2010) pandangan tentang penentuan situasi (definition of the situation) digunakan untuk menyatakan bahwa jika individu/kelompok disebut menyimpang, akan ada konsekuensi yang tidak diharapkan pada tingkat perilakunya. Pendapat serupa dikemukakan oleh Natasya (2013) subordinasi merupakan perilaku menomerduakan anak perempuan hampir disegala bidang, hingga perempuan ditempatkan sebagai posisi yang lebih rendah.

Subordinasi memiliki keyakinan bahwa salah satu jenis kelamin dianggap lebih penting atau lebih utama dibandingkan jenis kelamin lainnya. Sudah sejak dahulu terdapat pandangan yang menempatkan kedudukan dan peran perempuan yang lebih rendah dari laki-laki. Menurut Natasya (2013) marginalisasi merupakan terpinggirkannya kaum perempuan yang kebanyakan terjadi dibidang ekonomi di mana perempuan dianggap bukan seorang tulang punggung keluarga sehingga mendapatkan pendapatan yang lebih rendah, serta melakukan pekerjaan yang hanya bersifat teknis atau rutinitas. Menurut Natasya (2013) beban ganda (Double burden) biasanya dialami oleh wanita karier di mana tidak hanya mengurusi pekerjaan-pekerjaan rumah tangga namun juga berperan ganda memikirkan pekerjaan karirnya. Kekerasan (violence) suatu tindakan yang dilakukan oleh seseorang atau sejumlah orang yang berposisi kuat kepada seseorang atau sejumlah orang yang berposisi lemah yang dengan segala kekuatannya, baik secara fisik maupun non-fisik dengan sengaja dilakukan untuk menimbulkan penderitaan kepada obyek kekerasan.

Faktor lain yang disebutkan oleh Natasya (2013) yaitu stereotype yang melekat pada diri perempuan biasanya berbau negatif seperti lemah, penakut, cengeng dan sebagainya memunculkan perbedaan dengan anak laki-laki yang diberikan label kuat, pemberani dan tabah. Seseorang yang mendapatkan label negatif memicu pemikiran bahwa dirinya ditolak. Respon orang-orang yang menyimpang terhadap reaksi sosial menghasilkan penyimpangan sekunder yang mana mereka mendapatkan citra diri atau definisi diri sebagai seseorang yang secara permanen terkunci dengan peran orang yang menyimpang. Menurut Tuner (2010) Penyimpangan merupakan hasil atau akibat dari kesalahan sosial dan penggunaan kontrol sosial yang salah. Penolakan dapat mengurangi rasa percaya diri seseorang sehingga menyebabkan kesulitan mengembangkan diri dalam kehidupan bersosial. Pendapat lain diungkapkan oleh Nyoman (2013) stereotif terhadap jenis telah membakukan pandangan tentang bagaimana perempuan "seharusnya", dan bagaimana "laki-laki" seharusnya, tanpa memberi kesempatan untuk keluar dari ciri atau konstruksi yang telah ditetapkan oleh masyarakat.

Berdasarkan pendapat para ahli tersebut dapat disimpulkan bahwa faktor gender inequality dan perilaku responsif gender memiliki pengaruh yang kesinambungan. Bila orangtua melakukan pengasuhan berdasarkan identitas gender yang membedakan perlakuan anak laki-laki dan perempuan secara berbeda yang dituntun oleh budaya dan 
disesuaikan dengan personalitas anak maka akan menyebabkan anak kesulitan mengambil kesempatan dalam memperoleh atau menggunakan sumberdaya tertentu. Orangtua yang sejak dini sudah memberikan labeling pada anak maka akan membuat anak merasa terkotak-kotakan dalam melakukan mengakses sesuatu. Pemahaman tentang memperoleh atau menggunakan sumberdaya tertentu pada anak akan berkembang optimal bila anak sejak dini diajarkan untuk toleran terhadap kesetaraan peran antara laki-laki dan perempuan.

Penelitian terdahulu mengungkap fakta masalah ketidakadilan gender. Penelitian menurut Ampera (2012; vol 9); bahwa dalam tiga wilayah yaitu Deli Serdang, Binjai dan Medan tidak menyetujui adanya pemisahan gender dalam bidang rutin seperti daftar hadir dan pembagian duduk dalam kelas; $68,75 \%$, 48,75\% dan 54,17\%. Sedangkan, pembagian tugas piket dibedakan antara laki-laki dan perempuan, sebesar 43,75\%, 37,5\% dan 43,75\%. Berdasarkan data tersebut diketahui terdapat bias gender yang terjadi pada lingkungan sekolah. Terdapat perilaku yang tidak responsif gender pada murid laki-laki dan perempuan. Ketidakadilan gender yang masih terjadi pada pendidikan. Prestasi akademik serta peran kepemimpinan yang bias gender

Bila permasalahan gender inequality tidak di atasi maka akan menyebabkan remaja kesulitan memproporsikan diri dalam bersikap dan berperilaku serta bersaing secara sehat antar remaja untuk mencapai kesuksesan sesuai bidang dan bakatnya masing-masing. Untuk menemukan solusi, diperlukan kajian mendalam tentang hakikat perilaku yang responsif gender dan faktor-faktor penyebabnya. Oleh karena itu perlu dilakukan penelitian tentang pengaruh gender inequality terhadap perilaku responsif gender pada remaja.

\section{METODOLOGI PENELITIAN}

Metode penelitian ini menggunakan metode survei dengan pendekatan korelasi. Menurut pendapat Sugiyono (2010) metode survei untuk mendapatkan data dari tempat tertentu yang alamiah (bukan buatan), tetapi peneliti melakukan perlakuan dalam pengumpulan data, misalnya dengan mengedarkan kuesioner, tes, wawancara terstruktur dan sebagainya. Survei tersebut untuk mengetahui pengaruh antara satu atau lebih variabel bebas (independent variabel) yaitu variabel gender inequality dalam keluarga, terhadap variabel terikat (dependent variable) yaitu variabel perilaku responsif gender pada remaja di SMP NEGERI 149 Jakarta. Lokasi tersebut dipilih karena berdasarkan studi pendahuluan ditemukan dari 30 remaja, terdiri dari 15 remaja laki-laki dan 15 remaja perempuan ditemukan fakta gejala masalah ketidakadilan gender yang membuat salah satu gender mengalami kerugian.

Menurut pendapat Sugiyono (2012) survei adalah penelitian yang dilakukan pada populasi besar maupun kecil, tetapi data yang dipelajari adalah data dari sample yang diambil dari populasi tersebut. Populasi dalam penelitian ini adalah remaja usia 12-15 tahun di SMP Negeri 149 Jakarta yang memiliki saudara kandung berlainan jenis kelamin. Adapun jumlah populasi yang berhasil didapatkan sebanyak 170 siswa dan sample yang diambil menggunakan teknik proporsionate stratified random sampling. Sehingga sample yang didapatkan berjumlah 120 responden, terdiri dari 60 responden perempuan dan 60 responden laki-laki.

Teknik pengambilan data menggunakan angket tertutup dengan skala likert yaitu 1 sampai 4 poin. Untuk skor tertinggi 4 dan skor terendah 1. Instrument gender inequality yang digunakan peneliti mengacu pada dimensi menurut Natasya (2013) yaitu stereotype, subordinasi, marginalisasi, beban ganda (double burden) dan kekerasan (violence). Sedangkan untuk instrumen perilaku responsif gender peneliti mengacu pada dimensi menurut Puspitawati (2015) yaitu akses, partisipasi, kontrol dan manfaat. Pernyataan pada 
variabel gender inequality sebanyak 30 butir soal dan pada variabel perilaku responsif gender sebanyak 14 butir soal setelah dilakukan validitas dan reabilitas pada sebelumnya. Teknik analisis data menggunakan uji korelasi, uji signifikansi korelasi, uji determinasi, uji persamaan regresi dan uji signifikansi regresi. Pengujian sebelumnya sudah melalui uji prasyarat analisis diantaranya uji normalitas dengan kolmogorov-smirnov dan uji liniearitas regresi.

\section{HASIL DAN PEMBAHASAN}

\section{Karakteristik Responden}

Responden dalam penelitian ini adalah siswa siswi yang memiliki saudara kandung berlainan jenis kelamin di SMPN 149 Jakarta. Responden terdiri dari pelajar SMPN 149 yang berjenis kelamin laki-laki berjumlah 60 orang dengan persentase $(50 \%)$ dan responden perempuan berjumlah 60 orang dengan persentase (50\%). Berdasarkan tingkat pendidikan terakhir ayah responden, proporsi tingkat responden terbanyak pada tingkat SMA sebesar $49 \%$, pada tingkat SD sebesar $17 \%$, pada tingkat SMP sebesar $14 \%$, pada tingkat SMK sebesar $11 \%$, pada tingkat S1 sebesar $8 \%$ dan terendah pada tingkat D3 sebesar $1 \%$. Proporsi tingkat pendidikan ibu responden terbanyak pada tingkat SMA sebesar 37\%, pada tingkat SD sebesar $25 \%$, pada tingkat SMP sebesar $21 \%$, pada tingkat SMK sebesar $7 \%$, pada tingkat D3 sebesar $8 \%$ dan terendah pada tingkat S1 sebesar $2 \%$. Berdasarkan pekerjaan ayah responden, proporsi pekerjaan orangtua responden terbanyak adalah karyawan swasta sebanyak $42 \%$, wiraswasta sebanyak $28 \%$, dll sebanyak $23 \%$, buruh sebanyak $5 \%$ persentase pekerjaan terandah pada PNS dan Polisi sebanyak $1 \%$. Berdasarkan pekerjaan ibu responden, proporsi pekerjaan orangtua responden terbanyak adalah sebagai Ibu Rumah Tangga (IRT) sebanyak 85\%, buruh sebanyak 6\%, dll sebanyak $5 \%$, PNS sebanyak $2 \%$ persentase pekerjaan terendah adalah karyawan swasta dan wiraswasta sebanyak $1 \%$.

\section{Variabel Gender Inequality}

Gender inequality merupakan ketimpangan atau ketidakadilan akibat dari pemahaman individu atau kelompok yang terbentuk dari adat istiadat yang berkembang pada lingkungan sosial. Pada variabel gender inequality terdapat 5 dimensi yaitu stereotype, subordinasi, marginalisasi, double burden dan kekerasan. Dimensi terendah adalah dimensi marginalisasi dengan memperoleh persentase sebanyak 63\%. Dimensi marginalisasi rendah karena dalam keluarga responden tidak membedakan peran gender bagi perempuan dan laki-laki yang berdampak pada terkotak-kotaknya perilaku yang tidakadil yang menyebabkan kerugian bagi laki-laki dan perempuan. Hal ini sesuai dengan pendapat Bashin dalam Afandi (2019) ideologi yang menyatakan bahwa laki-laki lebih tingi daripada perempuan, bahwa perempuan harus dikontrol oleh laki-laki dan bahwa perempuan adalah bagian dari milik lakilaki. Perempuan mendapatkan hak yang sama untuk menentukan keputusan yang akan dipilih dan berhak menolak keputusan yang ditentukan oleh laki-laki.

Dimensi kekerasan memperoleh persentase mencapai $83 \%$ dan termasuk dalam kategori tinggi karena sebagian responden merasakan orangtua mudah memukul anak dan memarahi anak. Dampak dari kekerasan yang dilakukan oleh orangtua menimbulkan hubungan yang tidak baik antara orangtua dan anak. Sehingga anak merasakan tindakan kekerasan adalah tindakan negatif yang merugikan anak laki-laki maupun anak perempuan. Hal ini sesuai dengan pendapat Hartati (2015) ketidakadilan merupakan kondisi ketidakadilan yang diciptakan dari konstruksi sosial yang mengakibatkan laki-laki dan 
perempuan menjadi korban dalam pemahaman tersebut. Dampak dari kekerasan yang dilakukan oleh orangtua dapat menimbulkan hubungan yang tidak baik antara orangtua dan anak. Pada dimensi kekerasan laki-laki menjadi pihak yang dirugikan.

Tabel. 1 Persentase Dimensi variabel gender inequality

\begin{tabular}{llll} 
Dimensi & Semua Remaja & Laki-laki & Perempuan \\
\hline Stereotype & $75 \%$ & $75 \%$ & $74 \%$ \\
Subordinasi & $67 \%$ & $64 \%$ & $70 \%$ \\
Marginalisasi & $63 \%$ & $63 \%$ & $63 \%$ \\
Double burden & $70 \%$ & $68 \%$ & $71 \%$ \\
kekerasan & $83 \%$ & $85 \%$ & $82 \%$ \\
\hline
\end{tabular}

Dimensi subordinasi memperoleh persentasi sebanyak 67\%. Dampak dari subordinasi pada keluarga adalah menciptakan keyakinan bahwa salah satu jenis kelamin dianggap lebih penting atau lebih utama dibandingkan jenis kelamin lainnya yang mengakibatkan kerugian bagi anak laki-laki maupun anak perempuan. Dampak dari subordinasi pada keluarga adalah menciptakan keyakinan bahwa salah satu jenis kelamin dianggap lebih penting atau lebih utama dibandingkan jenis kelamin lainnya yang mengakibatkan kerugian bagi anak laki-laki maupun anak perempuan. Hal ini sesuai dengan pendapat ahli. Pendapat lain diungkapkan oleh Kornblum (1988:327) gender tersebut ialah satu set perangkat budaya yang menentukan maskulinitas dan feminitas, yang memunculkan peran gender atau seperangkat perilaku terhadap individual atau kelompok yang memperlakukan perempuan dan laki-laki dalam masyarakat secara tidak adil. Dampak lain yang ditimbulkan dimensi subordinasi bagi laki-laki dan perempuan adalah munculnya anggapan bahwa pekerjaan disesuaikan berdasarkan jenis kemalin seperti sekertaris hanya cocok untuk perempuan dan pemimpin hanya cocok untuk laki-laki. Hal ini sesuai dengan pendapat Aziz (2017) yang menggambarkan peran laki-laki dimasyarakat sebagai kepala keluarga, peran perempuan sebagai ibu rumah tangga, sifat perempuan biasanya digambarkan feminine dan laki-laki digambarkan maskulin. Cara untuk mengurangi subordinasi sehingga mewujudkan keadilan gender pada laki-laki dan perempuan dengan memperhatikan kebutuhan dan kegiatan antara laki-laki dan perempuan. Hal ini sesuai dengan pendapat Mastuti (2010) bahwa perhatian yang konsisten dan sistematis terhadap perbedaan-perbedaan perempuan dan laki-laki di dalam masyarakat yang disertai upaya menghapus hambatan-hambatan struktural dan kultural untuk mencapai kesetaraan gender.

Cara untuk mengurangi subordinasi sehingga mewujudkan keadilan gender pada lakilaki dan perempuan dengan memperhatikan kebutuhan dan kegiatan antara laki-laki dan perempuan. Hal ini sesuai dengan pendapat 91 Mastuti (2010) bahwa perhatian yang konsisten dan sistematis terhadap perbedaan-perbedaan perempuan dan laki-laki di dalam masyarakat yang disertai upaya menghapus hambatan-hambatan struktural dan kultural untuk mencapai kesetaraan gender. Kesetaraan yang adil adalah konsep yang mengakui faktor spesifik seseorang dan memberikan haknya sesuai dengan kondisi perorangan.

\section{Variabel Perilaku Responsif Gender}

Perilaku responsif gender merupakan kondisi di mana seorang laki-laki dan perempuan memiliki kesadaran gender untuk bersikap, berperan dan bertanggung jawab dengan 
menghargai dan memahami perbedaan kebutuhan antara laki-laki dan perempuan. Pada variable responsif gender terdapat 4 dimensi yaitu dimensi akses, dimensi partisipasi, dimensi kontrol dan dimensi manfaat. Dimensi akses merupakan dimensi tertinggi pada keseluruhan remaja. Dimensi akses memberikan kesempatan atau peluang antara laki-laki dan perempuan secara adil dan setara dalam memenuhi kebutuhan terhadap sumberdaya yang akan dibuat. Dimensi akses memiliki indikator yaitu: laki-laki dan perempuan mendapatkan kesempatan yang sama untuk memperoleh sumberdaya di sekolah dan indikator laki-laki dan perempuan mendapatkan kesempatan yang sama untuk menggunakan sumberdaya di sekolah. Dimensi akses memperoleh persentase tertinggi mencapai $82 \%$. Hal ini sesuai pendapat ahli yang diungkapkan oleh Mastuti (2010) responsif gender sebagai perhatian yang konsisten dan sistematis terhadap perbedaan-perbedaan perempuan dan laki-laki di dalam masyarakat yang disertai upaya menghapus hambatanhambatan struktural dan kultural untuk mencapai keadilan gender. Pendapat lain diungkapkan oleh Marlina (2010) pendidikan yang responsif gender dengan tidak melakukan pembedaan antara perempuan dan laki-laki.

Tabel 2. Persentase Dimensi perilaku responsif gender

\begin{tabular}{llll} 
Dimensi & Semua Remaja & Laki-laki & Perempuan \\
\hline Akses & $75 \%$ & $75 \%$ & $74 \%$ \\
Partisipasi & $61 \%$ & $60 \%$ & $62 \%$ \\
Kontrol & $72 \%$ & $73 \%$ & $71 \%$ \\
Manfaat & $68 \%$ & $70 \%$ & $66 \%$ \\
\hline
\end{tabular}

Untuk menjadi responsif gender siswa laki-laki dan perempuan mempunyai peluang yang sama untuk mengambil peran yang diinginkan di sekolah. Ada beberapa faktor yang mempengaruhi sikap responsif gender. Menurut pendapat ahli Balik (2018) dua faktor yang mempengaruhi terbentuknya sikap responsif, yaitu: faktor internal dan eksternal. Faktor internal atau bawaan yaitu faktor yang berupa bawaan sejak lahir dan meruapakan pengaruh keturunan dari salah satu sifat yang dimiliki salah satu dari kedua orangtuanya atau bisa juga gabungan atau kombinasi dari sifat orangtuanya. Faktor eksternal biasanya pengaruh yang berasal dari lingkungan di mana individu mulai belajar untuk menyesuaikan diri dengan dunia sosialnya yaitu teman-temannya. Pendapat yang serupa diungkapkan oleh Sadikin (2008:17) yang menyatakan bahwa ada beberapa faktor yang mempengaruhi sikap, antara lain yaitu; pengalaman pribadi, kebudayaan, orang lain yang dianggap penting, dan lingkungan di mana seseorang bersosialisasi

Dimensi partisipasi merupakan keikutsertaan seseorang atau kelompok dalam kegiatan atau dalam pengambilan keputusan di sekolah. Dimensi partisipasi merupakan dimensi terendah dengan persentase sebanyak $61 \%$. Dimensi partisipasi memiliki indikator yaitu: laki-laki dan perempuan mempunyai peran yang sama untuk mengambil keputusan di sekolah dan indikator keikutsertaan antara anak laki-laki dan anak perempuan dalam kegiatan di sekolah.

\section{Pengaruh Gender Inequality Dalam Keluarga Terhadap Perilaku Responsif Gender pada remaja}

Berdasarkan hasil penelitian diketahui nilai korelasi variabel gender inequality terhadap variabel perilaku responsif gender pada remaja didapati sebesar $-0,273$ dengan taraf 
signifikan $<0,05$ yaitu 0,03 artinya gender inequality berhubungan negatif dengan perilaku responsif gender pada remaja, angka tersebut berada pada tingkat hubungan dalam kategori rendah. Perilaku responsif gender merupakan kesadaran untuk bersikap, berperan dan bertanggung jawab dengan menghargai perbedaan antara laki-laki dan perempuan. Hal ini sesuai dengan pendapat ahli Mastuti (2010) bahwa perhatian yang konsisten dan sistematis terhadap perbedaan-perbedaan perempuan dan laki-laki di dalam masyarakat yang disertai upaya menghapus hambatan-hambatan struktural dan kultural untuk mencapai kesetaraan gender. Semakin tinggi gender inequality dalam keluarga maka perilaku responsif gender semakin rendah.

Hasil analisis uji regresi pengaruh gender inequality terhadap perilaku responsif gender pada remaja sebesar $-0,215$, hasil ini menunjukkan bahwa pengaruh gender inequality terhadap perilaku responsif gender pada remaja adalah signifikan dan negatif. Jika gender inequality dinaikan satu satuan, maka perilaku responsif gender akan berkurang sebesar 0,215 . Peneliti menemukan bahwa gender inequality berpengaruh negatif terhadap perilaku responsif gender pada remaja. Gender inequality merupakan konstruksi masyarakat tentang perbedaan laki-laki dan perempuan yang berkembang dimana individu tinggal. Hal ini sesuai dengan pendapat ahli Ardhie (2014) kesepakatan sebagai pembeda antar kaum laki-laki dan perempuan berdasarkan konstruksi sosial.

Sedangkan gender inequaliy berpengaruh positif terhadap perilaku responsif gender bila terdapat perubahan gender inequality menjadi gender equality dalam lingkuan sosial dimana individu tinggal. Gender adalah pandangan masyarakat tentang perbedaan fungsi, peran dan tanggung jawab antara laki-laki dan perempuan, sebagai hasil konstruksi sosio-kultural yang tumbuh dan sisepakati oleh masyarakat dengan proses yang sangat panjang, bisa berubah dari waktu ke waktu, tempat ke tempat, bahkan dari kelas ke kelas sesuai perkembangan zaman. Pendapat serupa diungkapkan oleh ahli Sztompka (2005:4-4) perubahan sosial adalah munculnya varian-varian baru sebagai hasil modifikasi selama berlangsungnya proses proses sosial dan interaksi sosial termasuk di dalamnya perubahan nilai, norma dan kultural. Berdasarkan para ahli dapat disimpulkan bahwa gender inequality merupakan kontruksi sosial yang dapat berubah melalui perkembangan zaman ke arah positif sehingga 96 ketidakadilan gender dapat berubah dan menciptakan keadilan gender (gender equality).

Peneliti menemukan bahwa gender inequality berpengaruh negatif terhadap perilaku responsif gender pada remaja. Gender inequality merupakan konstruksi masyarakat tentang perbedaan laki-laki dan perempuan yang berkembang dimana individu tinggal. Suatu sifat yang melekat atau dilekatkan pada kaum laki-laki maupun perempuan yang dikonstruksi secara sosial maupun kultural. Pendapat lain diungkapkan oleh Sanderson (2003:396) pada masyarakat tradisional laki-laki konsisten dengan perkerjaan yang bersifat maskulin dan perempuan lebih konsisten pada pekerjaan feminim.

\section{KESIMPULAN}

Hasil korelasi menunjukan bahwa terdapat pengaruh gender inequality terhadap perilaku responsif gender pada remaja kearah negatif. Gender inequality dalam keluarga berpengaruh negatif dengan perilaku responsif gender pada remaja dengan hubungan yang signifikan. Semakin tinggi gender inequality maka semakin rendah perilaku responsif gender pada remaja. Tingginya gender inequality dalam keluarga di karenakan masih adanya pemahaman pemisahan gender antara laki-laki dan perempuan yang terbentuk akibat lingkungan sosial dimana individu tinggal. Diharapkan orangtua memahami tentang gender agar dapat menciptakan keadilan gender antara laki-laki dan perempuan. Dimensi tertinggi 
pada variabel gender inequality dalam penelitian ini yaitu kekerasan bisa diminimalisir dengan berbagai cara. Diantaranya dengan cara oragtua tidak berperilaku kasar kepada anak laki-laki maupun anak perempuan. Sedangkan untuk variabel perilaku responsif gender dimensi akses didapati memiliki persentase lebih tinggi diantara dimensi yang lain. Dimensi yang memiliki indikator laki-laki dan perempuan mendapatkan kesempatan yang sama untuk memperoleh sumberdaya di sekolah dan indikator laki-laki dan perempuan mendapatkan kesempatan yang sama untuk menggunakan sumberdaya di sekolah.

\section{DAFTAR PUSTAKA}

Agus, Afandi. (2019). Bentuk-Bentuk Perilaku Bias Gender. Surabaya

Ampera, Dina. (2012). Kajian Kesetaraan Gender Dalam Pendidikan Di Sekolah Dasar Mitra PPL PGSD. Universitas Negeri Medan.

Annisarti, Siregar. (2015). Perbedaan Gender Dalam Perilaku Penemuan Informasi Akademis Di Kalangan Mahasiswa FISIP Universitas Airlangga. Surabaya.

Ardhie Raditya, Sosiologi Tubuh, Membentang Teori di Ranah Aplikasi (Cet. I; Yogyakarta, Kaukaba Dipantara, 2014), h. 245.

Balik, Arkadius. (2018). Pengaruh Sikap Responsif Dan Sikap Sosial Terhadap Hasil Belajar Kimia Peserta Didik Pada Materi Pokok Koloid Dengan Menerapkan Model Pembelajaran Kooperatif Tipe Group Investigation (GI) Peserta Didik Kelas XI IPA SMA Negeri 9 Kupang Tahun Pelajaran 2017/2018. Universitas Katolik Widya Mandira Kupang. HIm 16-18.

Dewa, Nyoman. (2013). Faktor-faktor Yang Mempengaruhi Bias Gender Penggunaan Konstrasepsi Pada Pasangan Usia Subur Di Desa Dawan Kaler Kecamatan Dawan Klungkung. Bali.

Erianjoni. (2013). Pelabelan Orang Minangkabau Pada Pelaku Penyimpangan Sosial: Studi Kasus Pada Dua Nagari Di Sumatera Barat. UNP.

Erlangga, E.W. (2014). Perbedaan Kinerja Polisi Lalu Lintas Berdasarkan Gender Ditinjau Dari Komitmen Organisasi dan Kesempatan Kerja Di Kantor Polda Jawa Barat. Bandung.

Marlina, Gazali. (2010). Pendidikan Responsif Gender. STAIN Sultan Qaimuddin Kendari.

Mastuti, S. Nugraha. (2010). Panduan Perencanaan dan Penganggaran Responsif Gender Bidang Perdagangan. Jakarta: Kementerian Pemberdayaan Perempuan dan Perlindungan Anak Kementerian Perdagangan.

Natasha, Harum. (2013). Ketidakadilan Gender Bidang Pendidikan: Faktor Penyebab, Dampak dan Solusi. Universitas Islam Negeri Sultan Syarif Kasim Riau. HIm.56.

Nuraida. (2017). Pola Komunikasi Gender Dalam Keluarga. Universitas Islam Negeri Raden

Fatah Palembang. 
Anggraini, Tarma, Mulyati, JKKP 7 (2) (2020) 210-219

Puspitawati, Herien. (2014). Funsi Keluarga, Pembagian Peran dan Kemitraan Gender Dalam Keluarga.

Puspitawati, Herien. (2015). Konsep, Teori dan Analisis Gender. Institut Pertanian Bogor.

Sugiyono. (2015). Metode Penelitian Kuantitatif, Kualitatif dan R\&D. Bandung: Alfabeta.

Sugiyono. (2012). Statistik Untuk Penelitian. Bandung: CV Alfabeta

Sadikin. (2008). Peningkatan Sikap Nasionalisme Melalui Pembelajaran IPS Dengan Metode Sosiodrama Di Sekolah Dasar. Tesis. Yogyakarta. Universitas Negeri Yogyakarta 